\title{
SIGNIFIKANSI NALAR IJTIHAD AL-JÂBIRÎ TERHADAP PEMAKNAAN ULANG KONSEP JIHAD ERA KONTEMPORER
}

\author{
Abid Rohmanu*
}

\section{Abstract}

Nowadays, in the modern era, we can obviously witness some groups of moslems still commit some terrors action to other religion and/or to outgroup-moslems just because of different understanding of Islamic dogma. These radical groups of moslem claim that their actions are on behalf of religious' belief. But, since the very beginning of revelation, Islam ask its followers to spread peace, harmony and prosperity among buman being, as Islam have essential principle "rahmah li al-alamin". So, certain perspectives or ways of understanding Islamic teaching applied by those groups are assumed to have emerged their negative response to other religion and out-group-moslems.

This paper examines the significance of rational understanding to Islam proposed by al-Jâbiri to reinterpretation of jihad in the modern context. The point of al-jâbirì's rational view is relevant factor to eliminate and minimize normative understanding to Islam.

Keywords: Bayânî, Irfânî, Burhanî, Qiyâs, Jihad, the Other, Ijtihad, Humanisme, Rasional.

BELAKANGAN masih sering terjadi tindakan-tindakan kekerasan yang mengatasnamakan agama, dengan bungkus doktrin jihad, yang dilakukan oleh sekolompok umat Islam. Tindakan ituyang mewujud dalam bentuk teror dan perilaku anarkis,

*Penulis adalah dosen Institut Agama Islam Sunan Giri Ponorogo (INSURI) Ponorogo. e-mail: nada_cuty2@yahoo.com. 
pelukaan fisik, penghilangan nyawa, dan pengrusakan properti serta harta benda-tidak saja ditujukan kepada the other tetapi juga kepada sesama umat Islam hanya karena perbedaan pemahaman keagamaan. Segala tindak kekerasan tersebut pada akhirnya memunculkan stigma bahwa Islam adalah agama teror, radikal, keras, dan ekstrim. Stigma tersebut jelas mendegradasikan Islam sebagai sebuah agama yang oleh pemeluknya diklaim sebagai rabmatan li al-âlamîn. Islam, dan tentu semua agama, diyakini pemeluknya mempunyai cita ideal humanisme (kemanusiaan), akan tetapi dalam perjalanan sejarahnya sering kali antara cita ideal tersebut dengan tataran praksis keagamaan terjadi gap. Pada tataran kedua justru sering berlangsung proses atau gejala dehumanisasi.

Banyak pihak menilai fenomena di atas, selain kadang bersifat politis, merupakan imbas dogmatisme dan tekstualisme dalam mempersepsi ajaran agama. Karena bagaimanapun pola keberagamaan seperti itu akan mempengaruhi sikap mental dan tindakan penganutnya dalam bentuk tindak kekerasan, klaimklaim kebenaran, ekslusivitas semisal pemurtadan, pengkafiran (takfir) dan bahkan fatwa hukum mati. Kalau persoalannya demikian, maka bentuk perlawanan terhadapnya adalah dengan mengikis pemahaman keagamaan yang literal-dogmatik dan mewacanakan serta menpraktekkan pendekatan terhadap Islam yang lebih rasional dan kontekstual. Hal tersebut dilakukan dengan menawarkan nalar ijtihad yang peka terhadap realitas sosial dan kemaslahatan kemanusiaan. Bagaimanapun, nalar ijtihad yang rasional akan menjadi kebutuhan tak terelakkan untuk membangun proyek humanisasi agama, tidak saja bagi mujtahid an sich, akan tetapi juga masyarakat awam.

Rasionalisme sebagai karakter yang melekat pada filsafat akan sangat membantu bagi proyek humanisasi agama. Apa yang dilakukan oleh Muhammad "Âbid al-Jâbirî dengan megaproyeknya "kritik nalar Arab" (KNA) yang ia wujudkan dalam trilogi kritik akal Arab relevan dengan tema bahasan ini. Dalam 
proyeknya, al-Jâbirî mengkampanyekan kesadaran ilmiah terhadap tradisi (turâts) ${ }^{1}$ dengan pendekatan-pendekatan epistemologis. Dalam studinya terhadap sistem nalar Arab-Islam yang selama ini beroperasi dalam budaya Arab-Islam, al-Jâbirî tiba pada kesimpulan bahwa sistem epistemologi Arab-Islam yang berkembang selama ini didominasi oleh epistem bayân yang teraplikasikan secara teoritis dalam qiyâs. ${ }^{2}$ Epistem bayâni, ${ }^{3}$ menurutnya, terlalu bersifat skripturalistik dengan bahasa sebagai basis logika yang membuatnya tidak peka terhadap realitas kemanusian.

\section{Mengenal Sekilas al-Jâbirî}

Muhammad 'Âbid al-Jâbirî adalah filosof Maroko kontemporer yang lahir pada tahun 1936 di kota Fekik, Maroko Tenggara, ${ }^{4}$ bagian dari wilayah Maghribi yang telah menelorkan banyak filosof klasik kenamaan semisal Ibn Rusyd, Ibn Khaldûn, Ibn Hazm dan al-Syâthibî. Kenyataanya, al-Jâbirî mengidolakan tokoh-tokoh tersebut karena dinilai sebagai motor semangat rasionalisme dalam konstelasi ilmu-ilmu keislaman. ${ }^{5}$ Maroko juga merupakan wilayah yang pernah menjadi daerah protektoriat

${ }^{1}$ Dalam perspektif al-Jâbirî, tradisi adalah kekayaan ilmiah atau metode berfikir yang diwariskan oleh orang-orang terdahulu (al-Qudâma'). Muhammad 'Abid al-Jâbirî, Post Tradisionalisme Islam, pen. Ahmad Baso (Yogyakarta: LKiS, 2000), 24.

${ }^{2}$ Qiyâs adalah mempertautkan asal (al-ashb) dengan cabang ( $\left.f a r^{2}\right)$, yang diketahui, nyata, riil (syâhid) dengan yang tidak diketahui (ghâıb) dan musyabbah dengan musyabbah bih karena adanya 'illah (causa yang sama).

${ }^{3}$ Epistem bayânî adalah seperangkat prinsip dan aturan untuk menafsirkan dan memproduk wacana dengan logika kebahasaan sebagai basis dan sumber pengetahuan. Al-Jâbirî, Bunyah al-'Aql al-'Arabi (Beirut: alMarkaz al-Tsaqâfî al-'Arabi, 1993), 64.

${ }^{4}$ Al-Jâbirî, Kritik Pemikiran Islam; Wacana Baru Filsafat Islam, ter. Burhan (Yogyakarta: Fakar Pustaka Baru, 2003), vi.

${ }^{5}$ Carol Kersten, "Review terhadap Buku al-Jâbirî Arab-Islamic Philosophy: A Contemporary Critique", dalam www.amazon.com., diakses bulan Mei 2003. 
Perancis. Karenanya, Bahasa Arab dan Bahasa Perancis merupakan bahasa resmi di wilayah itu. Dan karena itu pula alJâbirî banyak berdialog dengan tradisi pemikiran Perancis yang banyak diwarnai oleh analisa sejarah, kritik filsafat dan kritik nalar serta jauh dari bentuk-bentuk formalisme. ${ }^{6}$

Al-Jâbirî adalah seorang dosen, seminaris, dan penulis yang cukup produktif. Ada 17 karya dalam bentuk buku yang telah dihasilkan selain yang berbentuk makalah seminar, artikel dan yang semisalnya. ${ }^{7}$ Di antara karya-karyanya yang cukup populer adalah tiga buku berseri-nya-seri I dirilis tahun 1982, seri II tahun 1986, dan seri III tahun 1990_yang mewadahi KNA-nya, naqd al-'aql al-'arabî. Karya-karyanya telah banyak mendapatkan respon dari kalangan akademisi, baik dalam bentuk kajian-kajian maupun penterjemahan-penterjemahan.

\section{Kritik al-Jâbirî terhadap Nalar Ijtihad yang Membingkai Budaya Arab-Islam}

Kalau dalam seri I triloginya al-Jâbirî telah memaparkan konstruksi nalar peradaban Arab-Islam, yakni pilahan-pilahan epistem bayânî, 'irfânî,' dan burbânî,' maka dalam seri II al-Jâbirî

${ }^{6}$ Al-Jâbirî, Pos t..., xvi.

${ }^{7}$ Untuk mengetahui lebih lengkap karya-karyanya, lihat antara lain, alJâbirî, Post ..., XIII.

${ }^{8}$ Buku I triloginya berjudul Takwîn al-'Aql al-'Arabî (Libanon: Markaz Dirasat al-Wahdah al-'Arabiyah, 1989), Bunyah al-'Aql al-'Arabî; Dirâsah Tabliliyyah Naqdiyyah li al-Nuz̧hum al-Ma'rifah fì al-Thaqâfah al-'Arabiyyah (Beirut: al-Markaz al-Tsaqafi al-'Arabi, 1993), dan al-'Aql al-Siyâsî al-'Arabî; Muhaddidah wa Tajalliyyâtub (Beirut: al-Markaz al-Tsaqafî al-'Arabî, 1991).

${ }^{9}$ Nalar 'irfânî adalah epistemologi pengetahuan yang berasal dari tradisi Persia yang mendasarkan diri pada ilhâm, kasyf, pengalaman langsung (direct experience) yang bersifat intuitif sebagai sumber pengetahuan. Lihat al-Jâbirî, Bunyah..., 251.

${ }^{10}$ Ibid., 383. Epistem burhânî adalah sistem pengetahuan yang diadopsi dari tradisi Yunani. Dalam artian general, ia adalah aktivitas nalar untuk menetapkan kebenaran proposisi tertentu. 
secara detail mengulas masing-masing epistem tersebut dan di akhir ulasannya ia menawarkan pilihan epistem atau mensintesakannya dalam rangka memulai era baru "tadwîn".

Menurut al-Jâbirî, epistem yang genuine Arab adalah epistem bayânî dengan teori qiyâs sebagai titik sumbunya. Tidak mengherankan bila al-Jâbirî dalam banyak bukunya menyorot secara tajam sistem nalar ini. Sistem nalar ini merupakan pusat orientasi metodologis bagi keilmuan Arab-Islam, fikih (jurisprudensi), kalam (teologi), nậw dan balâghah. Semua disiplin keilmuan ini, menurutnya, digerakkan oleh logika kebahasaan. ${ }^{11}$ Sementara logika dan sistem bahasa itu sendiri secara signifikan mempengaruhi corak berpikir bahkan membatasi ruang lingkup pemikiran penuturnya. Persoalannya adalah bahwa Bahasa Arab yang dijadikan basis logika adalah bahasa yang diadopsi pada era tadwîn dari masyarakat Badui, masyarakat yang bercirikan primitif dan tertutup. Tidak salah bila logika kebahasaannya bercirikan hal serupa; a-historis dan materil. ${ }^{12}$

Berbicara tentang nalar ijtihad dalam epistem bayânî berarti berbicara tentang teori qiyâs, sebab ialah teori yang par excellence, the core of ijtihad dalam nalar bayânî, baik dalam lingkungan bahasa, teologi ataupun jurisprudensi. Hanya bila dirunut dari aspek kesejarahan, teori qiyâs lebih dulu eksis dalam ranah kebahasaan. Karena itu menurut al-Jâbirî dalam buku pertamanya, al-Syâfi'î bukanlah master arsitek dari qiyâs, ia hanya mengembangkan teori tersebut dari ranah kebahasaan ke dalam hukum Islam. ${ }^{13}$

Sebagaimana peradaban Arab-Islam adalah peradaban teks, al-Jâbirî menyatakan bahwa ijtihad atau qiyâs dalam tradisi bayânî belum beranjak dari "seputar teks" (hawl al-nash). Dua karakter yang sejak awal disandang teori ini adalah titik tolak dari lafazh menuju makna (al-ashl fî̀ al-laf̧̧ la fî̀ al-wâqi) dan orientasi

${ }^{11}$ Ibid., 13.

12Lihat al-Jâbirî, Takwîn al-'Aql al-'Arabî (Libanon: Markaz Dirâsat alWahndah al-'Arabiyyah, 1989), 77.

${ }^{13}$ Ibid., 124. 
berlebihan pada hal-hal yang partikular, parsial dan atomistik dari pada yang universal (perhatian pada kata atau lafaz dari pada tujuan-tujuan syara). Dalam tradisi bayânî kerja akal hanya dalam bingkai "elaborasi teks" (istitsmâr al-nash) dan inilah yang disebut dengan ijtihad dalam tradisi tersebut. ${ }^{14}$ Rasionalitas dan petunjuk hanya mungkin bila disandarkan dan mengabdi pada kandungan teks (ma'qûl al-nash).

Nalar ijtihad Arab-Islam, menurut al-Jâbirî, hanya berkisar pada level dilâlah al-khithâb (petunjuk wacana) yang kurang bisa menyentuh realitas sehingga signifikansi wacana menjadi absurd. Dilâlah al-khithâb bisa dalam bentuk petunjuk teks (dilâlah al-nash) atau petunjuk kandungan teks (ma'qûl al-nash). ${ }^{15}$ Petunjuk yang terakhir inilah yang bermuara pada teori qiyâs, itu artinya persoalan baru (al-far') harus dirujukkan (disamakan) secara ketat pada kandungan teks (ma'qûl al-nash) sebagai al-ashl untuk memperoleh penyelesaian atau status hukum. Sementara dalam proses tersebut mujtahid harus berjibaku dengan persoalan hubungan lafaz̧h dan makna yang menurut al-Jâbirî relasi pasangan tersebut bermasalah (musykilah al-zawj; al-lafz wa alma'na). ${ }^{16}$ Model seperti itu seringkali terjebak pada eksplanasi kebahasaan dari pada sisi intelektual-logis. Ijtihad dalam bingkai kebahasaan ini disebut oleh al-Jâbirî sebagai ijtihâd fi al-lughah dengan maqâshid al-lughah sebagai kata pemutus. ${ }^{17}$ Karena itu alJâbirî sampai pada kesimpulan bahwa teori qiyâs dalam nalar bayân̂ lebih banyak mengabdi pada "kuasa asal" (sulthah alash), 18 "kuasa lafaz" (sulthah al-laf $₹$ h), dan "kuasa keserbabolehan"

14Al-Jâbirî, Bunyah ..., 53 dan 63.

${ }^{15}$ Ibid., 56.

${ }^{16}$ Ibid., 41.

${ }^{17}$ Ibid., 63 dan 105.

18Ibid., 563. Sulthah al-Ashl (kuasa asal) bisa merujuk pada sulthah al-salaf atau pada teori qiyâs. "Kuasa salaf" sendiri pada dasarnya adalah "kuasa lafaz", karena kaum salaf mentransfer "kuasa-nya" kepada generasi sesudahnya (khalaf) melalui piranti khabar, yakni lafaz itu sendiri. Karena itu 
(sulthah al-tajwîy). ${ }^{19}$ Lafaz dan makna, asal dan cabang, jawhar dan 'aradh dalam tradisi bayânî merupakan pasangan-pasangan yang membingkai aktivitas berpikir dan relasi pasangan-pasangan tersebut bersifat tajwîz (keserbabolehan, bukan relasi kausalitas).

"Kuasa keserbabolehan" (sulthah al-tajwîn), tidak saja mewarnai relasi lafazh dan makna, akan tetapi juga mewarnai bagian dari kontruksi qiyâs, yakni 'illah. 'Illah adalah pilar utama dalam teori qiyâs, karena tanpanya tidak mungkin ada qiyâs antara al-far' dan al-ashl. 'Illah adalah sifat, sebagaimana sifat "memabukkan" pada khamr untuk melegitimasi keharaman khamr dan minuman lain yang sejenis. Mujtahid dengan metodemetode yang telah ditetapkan melakukan pencarian (istinbâth) 'illah sebagai alat jastifikasi (tabrîr) bagi berlakunya hukum asal pada cabang dengan perangkat wawasan kebahasaan dan unsur idiologis-teologis yang disandangnya. ${ }^{20}$ Karena itu 'illah bersifat zhan (spekulatif) dan karena itu pula relasi antara al-ashl dan al-far' adalah relasi keserbabolehan, bukan relasi kemestian sebagaimana dalam mantiq, ${ }^{21}$ dan itu yang terjadi pada qiyâs al'illah dalam ushûl al-fiqh, qiyâs al-dalâlah (qiyâs al-syâhid 'ala al-ghâib) dalam kalam dan tasybîh dalam disiplin bahasa.

\section{Memberikan Pondamen Rasional terhadap Nalar Ijtihad}

Dalam bukunya Bunyah al-'Aql al-'Arabî, sebagaimana dalam buku-bukunya yang lain, al-Jâbirî secara lantang menunjukkan keberpihakannya pada epistem burbânî yang diangapnya bisa mewadahi semangat rasionalismenya. Tetapi, sebagai muslim, ia tidak bisa mengelak keterlibatannya dengan tradisi bayân̂. Sebagaimana dikatakannya bahwa interaksi tradisi bayânî dengan

otoritas yang dipatuhi dalam bingkai peradaban Arab-Islam tidak saja otoritas teks dalam pengertiannya yang divine dan primer, akan tetapi bahkan yang profan dan sekunder seperti qawl al-salaf al-shâlih .

${ }^{19}$ Ibid., $560-561$.

${ }^{20}$ Ibid., 158, 171.

${ }^{21}$ Ibid., 172. 
teks merupakan bagian dari kenyataan sejarah, akan tetapi yang perlu dikritisi adalah cara dan metode kaum salaf dalam memahami teks tersebut yang dinilai kelewat konservatif. ${ }^{22}$ Terlebih, di tangan Syafi'i, sistem nalar tersebut dibakukan lewat teori qiyâs dan rumusan empat-sumber hukumnya, al-Qur'an, alSunnah, ijma' dan qiyâs. Dengan hal itu, ia pada dasarnya tidak mengorientasikan manusia agar mengamalkan sumber yang empat itu-sesuatu yang telah dilakukan oleh generasi-generasi sebelumnya - akan tetapi membatasi scope nalar Arab-Islam yang pengaruhnya sangat dirasakan, ${ }^{23}$ tidak saja bagi mereka bangsa Arab, akan tetapi semua wilayah yang berafiliasi kepadanya.

Memberikan solusi terhadap masalah itu, al-Jâbirî menawarkan adanya kolaborasi antara epistem bayân (rasionalitas teks) yang genuine Arab dengan epistem burbân̂ (rasioanalitas objektif) yang telah ditransfer oleh bangsa Arab dari tradisi Yunani lewat proses penterjemahan. Al-Jâbirî menyebut penyelarasan kedua sistem nalar tersebut sebagai ta'sîs al-bayân 'ala burbân ${ }^{24}$ (memberi landasan "rasionalitas-burhâni" pada tradisi bayânî) atau ta'shîl al-ushû́ ${ }^{5}$ (membangun dasar nalar ijtihad). Sementara itu ia menolak peran nalar 'irfânî yang menurutnya telah mengesampingkan akal dan menyerang dua epistem lainnya dari dalam. Al-Jâbirî menyebut nalar 'irfân̂̂ (irasionalitas yang rasional) sebagai sebuah pandangan dunia yang bersifat magis dan subjektif-dengan model kasyf dan ilhâm-nya-yang tidak mengenal obyektivitas dan parameter keilmuan karena tidak didasarkan pada alat-alat psiko-fisik manusia; potensi indera dan akal. ${ }^{26}$

${ }^{22}$ Ibid., 562.

23Ibid., 110.

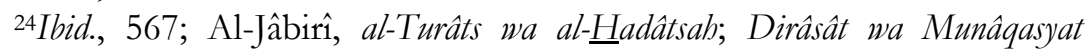
(Beirut: Markaz Dirâsat al-Wahndah al-'Arabiyyah, 1989), 188.

${ }^{25}$ Al-Jâbirî, al-Dîn wa al-Dawlah wa Tathbîq al-Syarîab (Libanon: Markaz Dirâsah al-Wahdah al-'Arabiyyah, 1996), 157.

26Al-Jâbirî, Bunyah..., 372 dan 379. 
Karena itu yang dimunculkan kemudian adalah metode yang beroperasi dalam sistem burhanî, yakni al-istintâj (deduksi, qiyâs silogisme) dan al-istiqra' (induksi) sebagai alternatif bagi qiyâs al'illah. ${ }^{27} \mathrm{Hal}$ itu dilakukan dengan sepenuhnya berpegang pada almaqâshid (tujuan-tujuan syari'ah) sebagai alternatif dari dilâlah allafz. (petunjuk lafazh), al-kulliyat (universalisme) alternatif dari atomisme, al-nazhrah al-târikhiyyah (analisis sejarah) alternatif dari analisis teks dan idrâk al-sabab wa al-musabbab (prinsip kausalitas) sebagai alternatif dari prinsip al-tajwî̀ (keserbabolehan).

Al-Istintâj adalah aktivitas penalaran untuk menetapkan kebenaran proposisi (qadliyyah)dengan cara mengaitkan proposisi yang satu dengan yang lain yang telah terbukti secara aksiomatik. Ativitas berpikir ini mensyaratkan pengetahuan tentang al-had alawsath (term tengah, term perantara) yang menyatukan kedua proposisi tersebut. Selain itu juga harus ada keserasiaan relasi antar terma dan kesimpulan, yang terakhir ini muncul secara otomatis. Sebaliknya al-istiqra' adalah determinasi analitis dari relasi sejumlah fenomena, kemudian diiringi proses generalisasi. ${ }^{28}$

Model penalaran qiyâs al-illah yang pada dasarnya adalah altamtsîl dan al-muqârabah, menurut al-Jâbirî_mengutip pendapat Aristoteles-merupakan varian dari al-istiqra' yang paling lemah dari sudut mantiq. Jadi bukan varian dari al-istintâj. Ia digolongkan pada al-istiqra' al-khithâbi (inferensia wacana) karena hanya merupakan tasybîh (penyamaan) dan al-muqârabah (kedekatan). Dalam tradisi bayânî, 'illah sendiri dipersyaratkan munâsib (berkesesuaian). Al-Munâsib sendiri secara etimologis adalah al-muqârabah, karena munâsib-nya 'illah bermakna sifat yang mendekatkan pada hukum (al-washf al-muqârib li al-hukm). ${ }^{29}$

${ }^{27}$ Ibid., 522 dan 567.

28Ibid., 376. Lihat juga tentang model logika ini dalam John Grier Hibben, Logic; Deductive and Inductive (New York, Chicago, Boston: Charles Scribner's Sons, 1905), 195. lihat juga, Irving M. Copy, Introduction to Logic (New York: Macmillan Publishing Co., Inc., 1978), 3.

${ }^{29}$ Ibid., 244. 


\section{Mainstream Pemaknaan Konsep Jihad}

Militansi dan radikalisme yang berkembang selama ini lebih banyak dijustifikasi oleh pelakunya dengan doktrin keagamaan. ${ }^{30}$ Suatu yang ironis memang, tatkala di sisi lain agama diyakini oleh pemeluknya sebagai penebar keselamatan, kasih sayang, dan kesejahteraan. Dalam konteks ajaran Islam, kekerasan terhadap "yang lain" selama ini lebih banyak diwadahi oleh doktrin jihad yang dimanipulasi pemaknaannya untuk kepentingankepentingan subjektif-ideologis kelompok-kelompok tertentu.

Jihad menjadi begitu identik dengan kekerasan dan sekaligus hal ini seakan menjadi faktor pembenar bagi persepsi kaum orientalis. Jihad berasal dari akar kata j-h-d yang dalam kitab Mu'jam al-Maqâyis fì al-Lughah, sebagaimana dikutip Quraysh Shihab, bermakna letih atau sukar karena memang jihad itu sukar dan meletihkan. Ada juga yang menyatakan bahwa jihad bermakna al-thaqah wa al-wus'u (kekuatan dan kemampuan). Kata ini bila tampil dalam bentuk perintah (sighah al-amr) bermakna alistifragh, yakni mencurahkan kekuatan dan kemampuan. Pengertian tersebut kemudian cenderung dimaknai secara fisik (perang), terlebih ada kata lain yang mempunyai akar kata yang sama, "ijtihâd" yang telah mempunyai batasan makna pada sesuatu yang non-fisik, olah pikir, dan ide.

Pemaknaan jihad juga mendapatkan inspirasinya dari intrepetasi parsial terhadap al-Qur'an yang banyak menampilkan kata jihad dengan berbagai derivasinya dalam pengertian "berjuang" terutama ketika kata jihad tersebut dipersambungkan dengan kata dampingan "fì sabil al-Lâb".

${ }^{30}$ Radikalisme keagamaan tentu bukan hanya pengalaman sejarah Islam. Agama Kristen, misalnya, pernah mentransformasikan "salib" dari simbol penderitaan dan pengorbanan suci kepada bendera perang berdasar klaim Konstantin, Kaisar Kristen Pertama, bahwa ia mendapat bisikan ilahi, "dengan salib engkau akan menang". Hal ini dianggap sebagai restu tuhan untuk melakukan perang atas nama agama. Lihat Alwi Shihab, Islam Inklusif; Menuju Sikap Terbuka dalam Beragama (Bandung: Mizan, 1998), 283. 
Seringkali pemaknaan konsep jihad juga hanya didasarkan pada pendekatan tekstual-etimologis sebagaimana yang telah dikonstruk para ulama pada era tadwîn dengan makna "perang" dan "pembunuhan". 31 Pemaknaan ini semakin menemukan signifikansinya tatkala sentimen terhadap kelompok, golongan, dan agama lain sengaja disulut oleh mereka yang hendak mempolitisasi agama untuk kepentingan partisan. Jihad dalam artian fisik sebagaimana yang telah terjadi pada era Rasul juga lebih banyak dimaknai secara normatif dan dijadikan acuan dalam menyikapi kelompok lain.

Padahal, hal tersebut murni kepentingan sosiologis dalam rangka memberikan ketentraman dan kesejahteraan dari gangguan secara fisik kelompok kafir Quraisy masa itu. Pendekatan terhadap teks keagamaan dan teks kesesejarahan yang tekstual-legalistik inilah yang membawa kepada militansi, ekstrimitas dan fundamentalisme. Pendekatan tekstual-legalistik dalam memahami konsep jihad akan mereduksi makna jihad itu sendiri. Jihad yang pada dasarnya mempunyai banyak makna yang bisa dikategorikan sebagai jihad menjadi identik dengan doktrin perang atau holy war dalam bahasa orientalis. Jihad kemudian hanya mempunyai makna yang sangat parsial seiring dengan telaah terhadap teks-teks keagamaan, utamanya alQur'an, yang juga bersifat parsial. Pendekatan terhadap teks-teks

${ }^{31}$ Salah satu contoh dalam hal ini adalah karya Ibn Rusyd, ulama yang hidup pada abad pertengahan, Bidâyah al-Mujtahid. Dalam kitab tersebut persoalan-persoalan perang dan damai diberi titel kitâb al-jibâd. Wajar bila kemudian masyarakat awam menilai jihad adalah perang. Sementara Mahmûd Syalthûth, ulama abad modern, dengan bahasan yang sama memberikan judul tulisannya al-Qur'an wa al-Qitâl. Lihat M. Dawam Rahardjo, Ensiklopedi al-Qur'an; Tafsir Sosial Berdasarkan Konsep-Konsep Kunci (Jakarta: Paramadina, 1996), 513. Dan memang untuk memperjelas subtansi jihad agar tidak diidentikkan dengan "memanggul senjata" al-Qur'an membedakan antara konsep qitâl (interaksi bersenjata) dengan konsep jihad. Lihat Alwi Shihab, Islam ..., 284. 
tentang jihad yang dilakukan tidak secara tematis semakin mendegradasi konsep jihad yang sejatinya kaya makna.

Pendekatan tekstual-legalistik ini, menurut Komarudin Hidayat, masih terasa dominan dalam wacana keislaman di Indonesia, terutama dalam dunia pesantren dan masyarakat secara umum. Menguatnya pendekatan tekstual-legalistik tidak bisa lepas dari kuatnya arus keilmuan fiqh di tingkat masyarakat yang belum banyak mengalami kontekstualisasi sejak keilmuan tersebut dibaku-bukukan pada era tadwîn. Sementara ada kesadaran yang cukup dalam dari masyarakat untuk tidak terjatuh pada kubangan dosa karena melanggar larangan Allah. Karena itu mereka mencari rujukan aturan-aturan hukum yang tegas dan populer yang terhimpun dalam kitab-kitab fikih klasik.

Pemaknaan konsep ijtihad selama ini lebih bersifat teosentris. Kekerasan-kekerasan yang mengatasnamakan agama diyakini sebagai sebuah pembelaan, pengabdian, dan dedikasi yang ditujukan kepada Tuhan, walaupun kemaslahatan kemanusiaan menjadi taruhannya. Prinsip bahwa agama diturunkan demi kepentingan dan kemaslahatan manusia dilupakan. Kesadaran akan kodrat dan hakikat manusia yang bebas dan rasional menjadi terkebirikan.

Tahap-tahap perkembangan pola berpikir manusia terpilah menjadi tiga fase; fase kosmosentris, teosentris, dan antroposentris. $^{33}$ Selama ini kebanyakan umat Islam masih terjebak pada kungkungan teosentrisme yang menjadikan mereka kurang sensitif terhadap problem kemanusiaan yang mengitari mereka. Islam menurut Kuntowijoyo adalah agama

32Pemahaman terhadap jihad bahkan seharusnya tidak saja bersifat tematis, bahkan juga melibatkan pemahaman-pemahaman terhadap ayat-ayat lain yang mengusung semangat toleransi, kerukunan dan persahabatan, selama ayat-ayat tersebut berada dalam konteks sosiologis yang sama.

${ }^{33}$ Amir Mu'allim, Mendalami Ide Islam Humanis (Salatiga: Pustaka Digital Millenials, 2005), 27. 


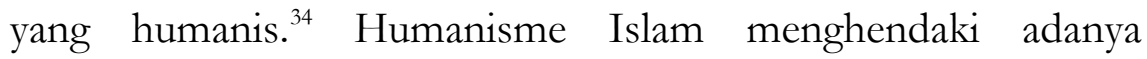
pendekatan-pendekatan yang bersifat antroposentris, manusia sebagai tujuan sentral. Beragama adalah kepentingan manusia, bahkan kewajiban ritual agama dari Tuhan-pun merupakan bagian dari kepentingan manusia.

\section{Relevansi Rasionalisme al-Jâbirî terhadap Pemaknaan Jihad Kontemporer}

Dari sekian referensi tentang pemikiran al-Jâbirî, penulis belum mendapatkan tema jihad yang dikupas al-Jâbirî. Walaupun begitu, dalam beberapa tulisannya, penulis temukan tentang sikapnya terhadap the big other (golongan di luar dirinya khususnya Barat) ketika berbicara dalam konteks kebangkitan Arab-Islam. Menurut al-Jâbirî, kebangkitan Arab-Islam lebih banyak didominasi oleh "mekanisme bela diri" dan bukan "mekanisme kebangkitan" yang sebenarnya. ${ }^{35}$ Artinya, bahwa kebanyakan masyarakat Islam mempersepsi the big other sebagai ancaman yang serius terhadap eksistensi dan identitas sang subjek yang inferior. Oleh karenanya, respons yang muncul adalah lebih pada perasaan sentimen, emosional, dan kebanggaan untuk berlindung dan memecahkan persoalan dengan rujukan tradisi masa lalu yang dianggap nyaris tanpa cacat. ${ }^{36}$ Wajar bila kemudian, semangat jihad dalam artian perang

${ }^{34}$ Happy Susanto, "Islam dan Problem Kemanusiaan" REPUBLIKA, 8 Agustus 2003.

35Al-Jâbirî, Post ..., 204.

${ }^{36}$ Al-Jâbirî menyatakan bahwa pengetahuan (tradisi) baik keagamaan, maupun yang rasional, metodologi dan industri adalah warisan dari para pendahulu yang harus disikapi secara objektif tanpa apriori bahwa keilmuan tertentu datang dari Barat dan harus dijauhi. Semuanya adalah bagian dari tradisi dan khazanah kemanusiaan yang mempunyai kontribusi terhadap peradaban manusia secara umum. Lihat Hasan Hanafi dan Muhammad 'Abid al-Jâbirî, Membunuh Setan Dunia; Meleburkan Timur dan Barat dalam Cakrawala Kritik dan Dialog, ter. Umar Bukhori (Yogyakarta: Ircisod, 2003), 113. 
lebih mudah dikobarkan. Menurut al-Jâbirî, semestinya respons sang subjek menghadapi the other yang perannya memang ambivalen $^{37}$ adalah tetap bersikap objektif sembari tetap pada kesadaran kejatidiriannya untuk melakukan passing over atas masa lalu dan masa kini sekaligus menuju masa depan dalam tingkat ide dan praksis. ${ }^{38}$

Apa yang dilakukan al-Jâbirî dengan proyeknya ta'sîs al-bayân 'ala burbân adalah sebentuk jihad intelektual dalam melawan bangunan kesadaran dan pemikiran Arab-Islam yang terhegemoni oleh masa lalu dalam bentuk teks dan bahasa. Bangunan pemikiran tersebut terasa normatif dan sempit sehingga membawa kepada praksis keagamaan yang rigid, eksklusif dan intoleran. Ia menawarkan bangunan epistemologi yang khas, yakni melalui pendekatan burhânî (rasional) dengan tetap mempertimbangkan tradisi pemikiran lokal. Semangat rasionalismenya yang tercermin dari tawaran metodenya, burhâni, silogisme atau al-qiyâs al-jâmi dengan tetap berpegang pada maqâshid al-syarîah, hikmah dan kemaslahatan sebagai landasan paradigmatik pada dasarnya lebih memperlihatkan nilai epistemologis ketimbang kekakuan logika formal sebagaimana teori qiyâs al-illah yang hanya mencari preseden-preseden ortodoksi dan otentisitas.

Pendekatan burbân̂ิ (rasional) dimunculkan untuk menghasilkan pengetahuan yang valid dan bangunan pengetahuan yang meyakinkan tentang persoalan alam dan sosial. Metode ini juga diakui telah menjauhkan tendensi subyektivitas dan emosional dalam penalaran, karena sebagai basis pengetahuan ilmiah empiris, epistem burhânî selalu menekankan pada akurasi, konsistensi, koherensi, dan

${ }^{37}$ Ambivalensi the other dalam hal ini Barat adalah bahwa satu sisi ia mewakili kekuatan dominasi, hegemoni dan imperialisme. Di sisi lain Barat juga merupakan simbol kemajuan dan kemodernan dengan segenap unsur yang dikandungnya.

${ }^{38}$ Al-Jâbirî, Post..., 205. 
keterukuran pengetahuan. Nalar ijtihad, ketika pergumulan agama dengan kehidupan kontemporer semakin kompleks dan majemuk, menyaratkan keterlibatan metode burhân $̂$ yang tentu tidak lagi hanya bisa disandarkan pada proposisi-proposisi yang bersifat metafisik dan teks dalam pengertiannya yang ketat. Keberpihakan kepada kemaslahatan manusia, pendekatan antara teks dengan realitas, antara normativitas dan historisitas merupakan karakter metode burbânı̂ yang sekaligus merupakan tuntutan dari Islam humanis. Dengan model seperti ini teks-teks keagamaan bisa dipahami dalam rasionalitas kehidupan sosial yang plural sehingga nilai Islam sebagai rabmatan li al-âlamîn tidak sekedar klaim.

Berbagai tindak kekerasan yang dilakukan oleh sebagian umat Islam dengan slogan jihadnya, tak pelak merupakan hasil dari konstruksi nalar bayân̂̀ sebagai sistem nalar yang dominan. Otoritas teks dan otoritas salaf yang hegemonik telah memunculkan pemaknaan konsep jihad yang berbau fisik saja. Fakta historis tersebut adalah, pertama; bahwa dalam interaksinya dengan kekuatan eksternal (nonmuslim), Islam sejak awal telah berhasil menancapkan kakinya melalui ekspansi militer jauh dari titik geografisnya. Kedua; hubungan internal umat Islam, terutama kelompok oposisi dan penguasa, sering kali diwarnai dengan konflik-konflik berdarah, sebagaimana kasus 'Utsmân bin 'Affân. ${ }^{39}$ Selain itu banyak teks-teks keagamaan yang secara literal-normatif mengabsahkan kekerasan dan menempatkan holy war sebagai jalan agama dalam memberangus mereka yang tidak sepaham. Menghadapi teksteks seperti tersebut di atas meniscayakan pembacaan yang kritis dan kontekstual-bahtsiyyah, bukan tekstual-ijtibadiyyah yang mengarah pada sikap mental dogmatik, defensif, apologis, dan polemis.

39Shihab, Islam ..., 283. 
Islam yang teraktualisasikan dalam sejarah, terutama era pasca kenabian tidak boleh dijadikan acuan tanpa telaah yang rasional dan kontekstual. Pada masa kenabian, perang sering kali merupakan pilihan yang wajar, karena tanpanya mustahil akan survive. Sebagaimana dikatakan oleh Ahmad Amîn, bahwa pada masa awal Islam, sentimen antar kelompok begitu dominan disebabkan masyarakat belum disatukan di bawah kepemimpinan atau pemerintahan tertentu. ${ }^{40}$ Masyarakat masih lebih suka disatukan pada ikatan-ikatan yang bersifat priomordial, kabilah, klan, dan ikatan darah. Selain itu, kemunculan Islam dengan klaim universalitasnya merupakan ancaman teologis dan ekonomis bagi masyarakat Arab nonmuslim. Untuk ancaman yang terakhir, bahwa seorang nabi, pemimpin keagamaan dalam konteks masa tersebut identik dengan kebesaran dan pengaruh golongan yang berimbas pada iklim dan kekuasaan ekonomi. Karenanya wajar bila terjadi ketegangan (tension) dan berlaku hukum rimba.

Pemberian landasan rasioanalitas burhânî pada sistem nalar bayânî_sebagaimana ide besar al-Jâbirî—akan menciptakan pemaknaan-pemaknaan yang kreatif terhadap konsep jihad, karena otoritas yang hegemonik bukan lagi preseden-preseden masa lampau, akan tetapi realitas (al-ashl fi al-wâqi' la fi al-nash) dan kebutuhan zaman. Penafsiran Islam yang humanis lebih melihat realitas dan kenyataan sosial dari pada teks dan orisinalitas masa lalu. Akal tidak lagi berperan mengukuhkan kebenaran teks akan tetapi menjalin relasi yang berkesesuaian (muthâbaqah) dengan hukum alam, sosial dan humanitas. Dalam konteks jihad, diakui memang bahwa perang dalam artian fisik merupakan bagian dari jihad, tapi itu bukan satu-satunya dan bisa saja hal tersebut hanya bersifat tentatif sesuai dengan konteks zaman. Jihad sebagai produk budaya harus dimaknai

40Ahmad Amîn, Fajr al-Islâm (Kairo: Maktabah al-Nahdlah alMishriyyah, 1950), 225. 
secara progresif dengan dihadapkan pada problem kemanusiaan kontemporer. Dalam konteks ini jihad bisa dimaknai secara emansipatoris sebagai upaya perlawanan terhadap peradaban yang destruktif dan penyusunan rencana strategis pemberdayaan masyarakat sipil (civil society). ${ }^{41}$

Quraish Shihab dalam tafsirnya menyatakan bahwa selaras dengan perkembangan kontemporer, jihad bisa mempunyai bermacam-macam bentuk; memberantas kebodohan, kemiskinan, dan penyakit. ${ }^{42}$ Hal ini selaras dengan pernyataan Dawam Rahardjo bahwa jihad dalam perkembangannya dimaknai sebagai upaya yang terarah dan terus menerus untuk menciptakan perkembangan (development) Islam dengan penekanan sarana nonsenjata. ${ }^{43}$ Ini berarti bahwa era kontemporer mengharuskan adanya penggeseran penekanan makna jihad dari bernuansa fisik kepada seruan untuk berkompetisi secara mental dan intelektual, tidak saja terhadap the others, akan tetapi juga terhadap sesama saudara seagama.

Dalam konteks humanisasi keilmuan Islam, kontribusi nalar infânî seyogyanya tetap dipertimbangkan, dalam hal-hal yang memang positif. Bagaimanapun, ilmu-ilmu keagamaan ('ulûm aldîn) sebagai bagian dari ilmu humaniora tentu tidak bisa mengikuti secara total tata kerja ilmu pengetahuan empirisilmiah dengan prinsip kausalitasnya. Nalar ijtihad kontemporer idealnya mempertimbangkan secara komprehensif kisi-kisi moral-spiritual dan pengalaman-pengalaman intelektual sekaligus.

Epistemologi al-Qur'an mengajarkan bahwa ilmu pengetahuan tidak "bebas nilai" akan tetapi harus berorientasi pada yang ruhaniah, spiritual, moral serta mempunyai relevansi

${ }^{41}$ Zuhairi Misrawi, "Dekontruksi Syari'at; Jalan Menuju Desakralisasi, Reinterpretasi dan Depolitisasi”, Tashwirul Afkar, 12 (2002), 22.

${ }^{42}$ M. Quraish Shihab, Wawasan al-Qur'an (Bandung: Mizan, 1998), 518.

${ }^{43}$ Rahardjo, Ensiklopedi ..., 516. 
sosial di samping relevansi intelektual. ${ }^{44}$ Untuk itu Amin Abdullah merumuskan model hubungan sirkuler antara tradisi bayânî, 'irfânî, dan burbânî. Akan tetapi sebelumnya harus dilakukan face off terhadap citra tradisi 'irfânî yang telah banyak diselewengkan kelompok-kelompok tarekat yang banyak keluar dari mainstream tradisi tersebut. ${ }^{46}$ Peradaban-peradaban ArabIslam atau yang berafiliasi kepadanya kebanyakan berada di wilayah timur sering dicitrakan Barat-terlepas dari kontroversi pencitraan ini-dengan feminin, peka secara emosional dan spiritual. Ini tak lepas dari tradisi irfânî yang tolak ukur serta validitas keilmuannya adalah universal reciprocity, empati, simpati, dan understanding others. ${ }^{47}$

\section{Catatan Akhir}

Berdasarkan paparan di atas, tergambar bahwa humanisasi praksis ajaran Islam mensyaratkan pendekatan yang rasional terhadap ajaran. Hal ini sesuai dengan tawaran al-Jâbirî bahwa sistem nalar Arab-Islam, bayânî, yang hegemonik harus dicairkan dan diberi landasan nalar burbânî. Ototoritas al-ashl dan otoritas lafaz̧ yang hanya berujung pada taqdîs al-afkâr al-diniyyah sudah selayaknya digantikan oleh otoritas akal dengan varian teori yang mendekatkan pada realitas humanitis dengan tetap berpijak pada nilai-nilai yang terkandung dalam teks, yakni maqâshid al-syarî́ah.

${ }^{44}$ Nanang Tahqiq, Dimensi Rasionalitas dan Spiritualitas dalam Ilmu Pengetahuan (Salatiga: Pustaka Digital Millennials, 2005), 6.

${ }^{45}$ Hubungan sirkuler antara tradisi bayâni, 'irfani dan burhâni menurut Amin Abdullah ditandai dengan adanya kerja sama antara ketiga tradisi pemikiran tersebut dengan masing-masing memberi masukan dan kritik yang membangun terhadap yang lain. Hal ini dilakukan dalam suasana dialogis, jauh dari eksklusifitas, dominasi dan hegemoni. Lihat M. Amin Abdullah, "al-Ta'wil al-'Tlmi; Ke Arah Paradigma Penafsiran Kitab Suci," dalam al-Jami'ah, 39 (Juli - Desember), 387.

${ }^{46}$ Lihat Ibid., 375..

${ }^{47}$ Ibid., 377 dan 382. 
Selain itu, polesan nalar 'irfânî dengan "pengalaman" (experience) sebagai sumber pengetahuan dan pendekatan yang intersubjektif akan semakin melapangkan proyek Islam humanis. Oleh karenanya, dalam konteks bahasan ini, jihad bisa bermakna perlawanan terhadap segala yang berbau dehumanisme dan secara bersamaan berarti pula menciptakan tatanan kehidupan yang humanitarian (berperikemanusiaan). Dengan praktek tersebut diharapkan pesan Islam sebagai agama yang rabmatan lil al-'âlamîn "tidak jauh panggang dari api". Semoga!

\section{Daftar Pustaka}

A. Luthfi al-Syaukanie, "Tipologi dan Wacana Pemikiran Arab Kontemporer", Paramadina, Vol. I, No. I, Juli-Desember 1998. Anmad Amîn, Fajr al-Islâm (Kairo: Maktabah al-Nahdlah alMishriyyah, 1950).

Al-Jâbirî, al-Dîn wa al-Dawlah wa al-Tatbbîq al-Syarîab (Libanon:

Markâz Dirâsah al-Wahahdah al-'Arabiyyah, 1996).

, Bunyah al-'Aql al-'Arabî (Beirut: al-Markaz al-

Tsaqâfî al-'Arabî, 1993).

Kritik Pemikiran Islam; W acana Baru Filsafat Islam, ter.

Burhan (Yogyakarta: Fajar Pustaka Baru, 2003). , Takwîn al-'Aql al-'Arabî (Libanon: Markâz Dirâsat al-Wahdah al-'Arabiyyah, 1989).

Alwi Shihab, Islam Inklusif; Menuju Sikap Terbuka dalam Beragama (Bandung: Mizan, 1998).

Amir Mu'allim, Mendalami Ide Islam Humanis (Salatiga: Pustaka Digital Millenials, 2005).

Carol Kersten, "Review terhadap Buku al-Jâbirî Arab-Islamic Philosophy; A Contemporary Critique", dalam www.amazon.com., diakses bulan Mei 2003.

Happy Susanto, "Islam dan Problem Kemanusiaan" REPUBLIKA, 8 Agustus 2003. 
Hasan Hanafi dan Muhammad 'Abid al-Jâbirî, Membunub Setan Dunia: Meleburkan Timur dan Barat dalam Cakrawala Kritik dan Dialog, ter. Umar Bukhori (Yogyakarta: Ircisod, 2003).

Irving M. Copy, Introduction to Logic, New York: Macmillan Publishing Co., Inc., 1978.

John Grier Hibben, Logic; Deductive and Inductive (New York, Chicago, Boston: Charles Scribner's Sons, 1905).

M. Amin Abdullah, "al-Ta'wil al-Tlmi; Ke Arah Paradigma Penafsiran Kitab Suci", dalam al-Jamiah, Volume 39, JuliDesember, 2002.

M. Dawam Rahardjo, Ensiklopedi al-Qur'an; Tafsir Sosial Berdasarkan Konsep-Konsep Kunci (Jakarta: Paramadina, 1996).

M. Quraish Shihab, W awasan al-Qur'an (Bandung: Mizan, 1998).

Muhammad 'Abid al-Jâbirî, Post Tradisionalisme Islam, ter. Ahmad Baso (Yogyakarta: LKiS, 2000).

Nanang Tahqiq, Dimensi Rasionalitas dan Spiritualitas dalam Ilmu Pengetahuan (Salatiga: Pustaka Digital Millennials, 2005).

Pier Paolo Giglioli (ed.), Language and Social Context (New York: Penguin Books, 1985).

Zuhairi Misrawi, "Dekontruksi Syari'at; Jalan Menuju Desakralisasi, Reinterpretasi dan Depolitisasi", Tashwirul Afkar, 12, 2002. 